\title{
Students' Achievement in Math and Science: How Grit and Attitudes Influence?
}

\author{
Masooma Ali Al-Mutawah ${ }^{1} \&$ Moosa Jaafar Fateel ${ }^{1}$ \\ ${ }^{1}$ Bahrain Teachers College, University of Bahrain, Kingdom of Bahrain \\ Correspondence: Masooma Ali Al-Mutawah, Bahrain Teachers College, University of Bahrain, Kingdom of \\ Bahrain. Tel: 973-1743-7152. E-mail: malmutawah@uob.edu.bh
}

Received: September 29, 2017

doi:10.5539/ies.v11n2p97
Accepted: November 27, $2017 \quad$ Online Published: January 26, 2018

URL: https://doi.org/10.5539/ies.v11n2p97

\begin{abstract}
Many recent studies in the field of mathematics and science education have been studying the effect of non-cognitive factors in students' achievement such as emotions, attitudes, values, beliefs, motivation, anxiety and grit. For example, attitude has been an important area in science education, and there have been many attempts to measure students attitudes to understand why they prefer a specific science subject (Reid; 2006). Zimmerman and Brogan (2015) stated that 'grit predicts successful performance in a variety of contexts and found to be positively correlated with undergraduate grade average.' Unfortunately, there are very few attempts if any have been studying the effect of grit on students' academic achievement in Bahrain. Bahrain is an important economic sector in the Arabic Gulf region; it has very ambitious and competitive developing economical and educational vision. This study aims to find relationships between students' level of grit and attitudes toward mathematics and science and the academic achievements in Bahrain secondary schools. 'Grit questionnaire' was adapted from Duckworth et al. (2007), and was administered to a total of 646 secondary school students. 'Attitudes toward mathematics' questionnaire was adapted from TIMSS (2011), and administered to a total of 349 secondary school students. 'Attitudes toward science' questionnaire was adapted from TIMSS (2011), and administered to a total of 297 secondary school students. The results showed that grit is positively and significantly correlated to academic achievement in math only, while attitudes towards math and science was positively and significantly correlated to academic achievement in both subjects.
\end{abstract}

Keywords: grit, attitude and academic achievement

\section{Introduction}

Pajares (2002, p. 117) found that students who can't overcome their life stress and turmoil often struggle in schools. Hannula (2004, p. 107) describes some of the non-cognitive factors as "Affective variables which can be seen as indicative of learning outcomes or as predictive of future success."

Angela Duckworth who spent more than 12 years studying the effect of grit on achievement mentioned that self-control and grit might be the keys to a better life more than talent and IQ (Duckworth, 2014). Even though some authors did not agree with all her say (Socol, 2014), but she did an amazing job in studying the effect of non-cognitive factors on achievement. She defined grit as cited by Emily Hanford (2013) as "the tendency to sustain interest and sticking with things over very long term until you master them". StoItz (2015) defined grit as "Your capacity to dig deep and do whatever it takes - even sacrifice, struggle and suffer - to achieve your most worthy goals in the best ways."

Gardner (1975) stated 'The first task and central purpose of science education is to awaken in the child the sense of the joy, the excitement, and the intellectual power of science.' He wondered if our students enjoy the things they do in science! He ended his argument saying that 'Science education developer should care about developing the Joy, excitement, satisfaction, wonder, and delight since the development of cognitive abilities in science is not enough and that the ultimate aims of science education should include attitudes as well.'

The new research in education is encouraging considering grit as an important aspect to improve school performance. Seider, as cited by Pappano (2013), says that "We have some really good research showing the correlation between grit and student success but a very little research demonstrates that we can increase the level of grit." Pappano also wrote that "the word grit risks being overused, but the suggestion that how students 
approach learning may be as critical as what they learn is resonating with educators.

Furthermore, these highlights and descriptions of the importance of grit and attitude in success in mathematics and science was the reason for conducting this study among the students in Bahrain schools. Findings from this study will be helpful tool to teachers, curriculum developers and parents to understand the importance of grit and attitude in mathematics and science education to find ways to improve students' performance.

\section{Literature Review}

Numerous studies in science education investigated the factors influence academic achievement. Most of these studies concentrate on cognitive factors, but recent studies started to address the importance of the non-cognitive factors in academic success. Tsereteli et al. (2010) investigated the relationship between factors like sense of success with parents' involvement in school life, class climate, and school culture. They administered a questionnaire to 5385 students (age 15-16) and found that some of the best predictors for the sense of success in school environment were non-cognitive factors like parent learning attitudes, involvement and belief of child's success and finally teachers teaching style.

In a study for Tough (2012), he explains that non-cognitive skills such as the grit could be more important than the cognitive skills to determine how successful the student could be in school and throughout life. He also found that students who can't overcome their life stress and turmoil often struggle in schools. Tough also explains as cited by Bengtson (2013) 'the development of character, grit, and curiosity are as important, if not more so as the narrow range of cognitive skills.' Sommerfeld (2011) stated that other than the traditional measures (GPA and standardized test scores) of college readiness, a new consideration of non-cognitive factors started to mark a significant discussion of college success.

In 2012, Diaz et al. (2012) surveyed a sample of age 14-50 in Peru. They used the five factors model of personality traits and the Grit personality trait. Their results confirm that both socio-emotional and cognitive skills are valued equally, and they are both important correlates of earnings. Culina et al. (2014) did two cross-sectional studies; they found that grit demonstrated associations with engagement, meaning, and pleasure. They explained that pursuing engagement was more strongly associated with the perseverance of effort, whereas pursuing pleasure was more strongly (inversely) associated with consistency of interests over time. Their findings were also suggesting that what makes individuals happy depends on their differences in grit. This study can help educators to look to passion as a tool for building students' long-term goals.

Wallace (2010) presented a paper at the Australian Council for Adult Literacy Conference which draws a study that explores concepts illuminate the learning process; he concluded that engagement with concepts like grit might assist in developing transformed practice. Burtner (2005) found that non-cognitive factors like perception, confidence, and expectations found to be significant predictors of persistence in engineering.

Chris Gabrieli as cited by Sparks (2015) mentioned that having the proper tool to know which things are working and which things are not is as important as working on non-cognitive factors. Sparks mentioned that is why researchers from Educational Testing Service are testing different variations of non-cognitive factors questions, as they did with 140 students in grades 4, 8, and 12 from a three-state area around Columbia. For example, fourth-grade students did not know what "committed to goals" or "experiencing failure" meant. As a result, the researchers changed the questions to be "continue to work toward my goals" and "making mistakes." These small changes in phrasing questions can change the results to better understand students' answers. They also found that students in all grades showed no difference in how they rated themselves on questions that asked them about their mindset in different contexts.

Gardner (1995) cited a good example of an instrument developed by Coulson (1992) for measuring the attitudes towards science. Her instrument consisted of four scales, assessing students' confidence in doing science, their enjoyment of science at school, and their feelings about the personal usefulness of doing science, and their evaluation of the appropriateness of science for young children. Each dimension was measured separately with an 8-item Likert scale. Researchers agree with Gardner suggestion of using similar procedures for studying attitudes to science to get better research quality.

Osborne et al. (2003) reviewed the major literature about attitudes to science over the past 20 years; they argued that there is a greater need for research to identify the aspects of science teaching, classroom environment and activities which motivate students, raise their interest and make school math and science more engaging for students. So the teacher should encourage students to maintain their grit to be successful in their future careers. Pajares (2002) suggested that parents and teachers should convey the message that academic success is a matter of desire, effort, and commitment. 
Rojas (2015) studied two sample groups of undergraduate students; he used Grit Scale survey to explore the relationships between creativity, perseverance, motivation, and achievement. He found that grit had a correlated two-factor structure reflecting interest and effort; there also was evidence that grit can mediate the relationships between motivation and grades. Diaz et al. (2012) conducted a study in Peru to measure both cognitive (ex: Vocabulary, verbal fluency, and numeracy/problem-solving). And non-cognitive (socio-emotional) skills by using the (Big-five Factors; Grit- Duckworth et al. 2009). Their finding showed that both the non-cognitive and cognitive skills were equally valued and they are both important correlates of earnings.

Non-cognitive factors not only affect students, but it can also determine teacher effectiveness which directly can affect students' achievement. In 2009, Duckworth and others made a study among 390 teachers in public schools, which completed measures of optimistic explanatory style, grit, and life satisfaction. Their study findings showed that grit and life satisfaction were significant predictors. They suggested that positive traits should be considered when selecting teachers. They also found more educated adults were higher in grit than were less educated adults of equal age. Also, their findings suggested that the achievement of difficult goals entails not only talent but also the sustained and focused application of talent over time.

\section{Research Aims}

This study aims to determine the following:

Identify students' level of grit, attitudes towards mathematics, and attitudes towards science.

Find any relationships between students' level of grit, and their level of academic achievement.

Find any relationships between students' attitudes toward mathematics and their level of academic achievement in the target subject.

Find any relationships between students' attitudes toward science and their level of academic achievement in the target subject.

\section{Research Method}

This is a descriptive approach research design. The focus of this study is to investigate if there is any correlation between grit and attitudes and students' achievement in math and science. It used a quantitative approach method which is the questionnaire. 'Grit questionnaire' consisted of 12 items was adapted from Duckworth et al. (2007) and translated into Arabic. 5-Items Likert scale was used in this questionnaire focusing on the five responses: very much like me, mostly like me, somewhat like me, not much like me, not like me at all.

Also, attitudes toward mathematics questionnaire (Mathematics and students) items only and attitudes toward science questionnaire (Science and students) items only were adapted from TIMSS (2011) and translated into Arabic. Attitudes towards mathematics questionnaires consisted of 20 items, similarly attitudes towards science questionnaire consisted also of 20 items. Both questionnaires focused on three categories: students like learning mathematics/science 5 items, students' value mathematics/science 6 items, and students confident in mathematics/science 9 items. These questionnaires offered a choice of 4 responses: agree a lot, agree a little, disagree a little, and disagree. This scale allows the students to express how much they agree or disagree on a particular statement.

Cronbach's Alpha reliability of Grit questionnaire was tested and found to be 0.629 which is acceptable. The overall 20 item mathematics questionnaire has the reliability of 0.827 and considers a high reliability. The individual scales liking mathematics, valuing mathematics and confidence in mathematics also has high reliability ranging from 0.810 to 0.889 . The overall 20 item science questionnaire has the reliability of 0.958 and considers a high reliability. The individual scales liking science, valuing science and confidence in science also has high reliability ranging from 0.810 to 0.889 .

A total of 646 students from secondary schools in Bahrain participated in the study.

\section{Data Analysis}

Data were analyzed using SPSS. Descriptive analysis on items in each questionnaire was performed. The following equation was used to interpret the data from the questionnaires:

$$
\begin{aligned}
\text { Interval Length } & =(\text { Highest score }- \text { Lowest score }) / \text { number of scores } \\
& =(5-1) / 5=0.8 \text { for the Grit Questionnaire } \\
& =(4-1) / 4=0.75 \text { for the Attitude Questionnaires }
\end{aligned}
$$


Table 1. Distribution of means according to Likert's scale

\begin{tabular}{cccc}
\hline \multicolumn{2}{c}{ Grit Questionnaire } & \multicolumn{2}{c}{ Attitude Questionnaires } \\
\hline The accepted Meander $(\mathrm{M})$ & The level & The accepted Meander $(\mathrm{M})$ & The level \\
\hline $1.0 \leq M<1.8$ & Very Low & $1.00 \leq M<1.75$ & Low \\
$1.8 \leq M<2.6$ & Low & $1.75 \leq M<2.50$ & Satisfactory \\
$2.6 \leq M<3.6$ & Moderate & $2.50 \leq M<3.25$ & Moderate \\
$3.6 \leq M<4.2$ & High & $3.25 \leq M<4.00$ & High \\
$4.2 \leq M<5.0$ & Very High & & \\
\hline
\end{tabular}

The following sections report the results.

\subsection{Descriptive Statistics for the Grit Questionnaire}

Table 2. Descriptive statistics of grit questionnaire items

\begin{tabular}{|c|c|c|c|c|c|c|c|}
\hline \multirow{2}{*}{ N. } & \multirow{2}{*}{ Item } & \multicolumn{2}{|c|}{ Math } & \multicolumn{2}{|c|}{ Science } & \multicolumn{2}{|c|}{ Total } \\
\hline & & Mean & $\mathrm{SD}$ & Mean & SD & Mean & $\mathrm{SD}$ \\
\hline 1 & I have overcome setbacks to conquer an important challenge. & 3.84 & 0.97 & 3.73 & 1.05 & 3.79 & 1.01 \\
\hline 2 & New ideas and projects sometimes distract me from previous ones. & 3.34 & 1.07 & 3.19 & 1.07 & 3.26 & 1.07 \\
\hline 3 & My interests change from year to year. & 3.85 & 1.17 & 3.94 & 1.21 & 3.90 & 1.19 \\
\hline 4 & Setbacks don't discourage me. & 3.82 & 1.07 & 3.85 & 1.12 & 3.83 & 1.09 \\
\hline 5 & $\begin{array}{l}\text { I have been obsessed with a certain idea or project for a short time } \\
\text { but later lost interest. }\end{array}$ & 2.94 & 1.26 & 3.01 & 1.33 & 2.97 & 1.30 \\
\hline 6 & I am a hard worker. & 3.95 & 1.02 & 4.05 & 0.97 & 4.00 & 0.99 \\
\hline 7 & I often set a goal but later choose to pursue a different one. & 3.46 & 1.27 & 3.43 & 1.22 & 3.44 & 1.24 \\
\hline 8 & $\begin{array}{l}\text { I have difficulty maintaining my focus on projects that take more } \\
\text { than a few months to complete. }\end{array}$ & 3.15 & 1.27 & 3.09 & 1.31 & 3.12 & 1.29 \\
\hline 9 & I finish whatever I begin. & 4.03 & 0.99 & 3.97 & 1.13 & 4.00 & 1.06 \\
\hline 10 & I have achieved a goal that took years of work. & 3.06 & 1.35 & 3.05 & 1.39 & 3.06 & 1.37 \\
\hline 11 & I become interested in new pursuits every few months. & 3.48 & 1.22 & 3.44 & 1.17 & 3.46 & 1.20 \\
\hline 12 & I am diligent. & 4.08 & 0.95 & 4.17 & 0.93 & 4.12 & 0.94 \\
\hline Total & & 3.58 & 1.13 & 3.58 & 1.16 & 3.58 & 1.15 \\
\hline
\end{tabular}

Table 2 shows that arithmetic mean of math students' responses to the instrument was (3.58) which is high. Arithmetic mean of math students' responses was between (4.08) and (2.94) for grit items, which means that math students were showing high to moderate grit level.

While arithmetic mean of science students' responses to the instrument was (3.58) which is high. Arithmetic mean of science students' responses was between (4.17) and (3.01) for grit items which means that science students were also showing high to moderate grit level.

Arithmetic mean of total math \& science students' responses was (3.58), which means students grit in both math and science was high. While the highest arithmetic mean for both math and science was for the item ' $I$ am diligent' which means students believe that they are doing their best work. The lowest arithmetic mean also for both math and science was for the item 'I have been obsessed with a certain idea or project for a short time but later lost interest' which was surprising especially that they are different groups of students. That mean students don't have enough grit to continue a project that required long time.

\subsection{Descriptive Statistics for the Attitudes toward Mathematics Questionnaire}

Table 3. Descriptive statistics of attitudes toward mathematics items categories

\begin{tabular}{lcc}
\hline Attitudes toward mathematics items categories & Mean & SD \\
\hline Liking mathematics (5 items, from 1-5) & 2.94 & 1.12 \\
Valuing mathematics (6 items, from 6-11) & 3.14 & 0.95 \\
Confidence in mathematics (9 items, from 12-20) & 2.90 & 0.97 \\
\hline
\end{tabular}


Table 3 shows that arithmetic mean of the responses to the instrument was (2.94) for Liking mathematics items, and (3.14) for Valuing mathematics items, and (2.90) for Confidence in mathematics items. All items showed a moderate level, which means students showed moderate level of attitude towards mathematics. All these items need to be addressed since they could be important factors affecting the achievement negatively if not addressed carefully.

Table 4. Descriptive statistics of attitudes toward mathematics questionnaire items

\begin{tabular}{|c|c|c|c|}
\hline \multirow{2}{*}{ N. } & \multirow{2}{*}{ Item } & \multicolumn{2}{|c|}{ Math } \\
\hline & & Mean & SD \\
\hline \multicolumn{4}{|c|}{ Liking mathematics } \\
\hline 1 & I enjoyed learning mathematics & 3.16 & 0.99 \\
\hline 2 & I wish I did not have to study mathematics & 2.75 & 1.19 \\
\hline 3 & Mathematics is boring & 2.84 & 1.12 \\
\hline 4 & I learn many interesting things in mathematics & 2.98 & 1.05 \\
\hline 5 & I like mathematics & 2.97 & 1.26 \\
\hline \multicolumn{4}{|c|}{ Valuing mathematics } \\
\hline 6 & I think learning mathematics will help me in my daily life & 2.99 & 1.07 \\
\hline 7 & I need mathematics to learn other school subjects & 2.92 & 1.01 \\
\hline 8 & I need to do well in mathematics to get into the university & 3.52 & 0.76 \\
\hline 9 & I need to do well in mathematics to get the job I want & 3.24 & 0.95 \\
\hline 10 & I would like a job at involves using mathematics & 2.61 & 1.10 \\
\hline 11 & It is important to do well in mathematics & 3.53 & 0.78 \\
\hline \multicolumn{4}{|c|}{ Confidence in mathematics } \\
\hline 12 & I usually do well in mathematics & 3.24 & 0.84 \\
\hline 13 & Mathematics is more difficult for me than for many of my classmates & 2.98 & 1.04 \\
\hline 14 & Mathematics is not one of my strength & 2.66 & 1.08 \\
\hline 15 & I learn things quickly in mathematics & 3.08 & 0.93 \\
\hline 16 & Mathematics make me confused and nervous & 2.57 & 1.07 \\
\hline 17 & I am good at working out difficult mathematics problems & 2.66 & 1.00 \\
\hline 18 & My teacher thinks I can do well in mathematics & 3.50 & 0.75 \\
\hline 19 & My teacher tells me I am good at mathematics & 3.38 & 0.86 \\
\hline 20 & Mathematics is harder for me than any other subject & 2.05 & 1.12 \\
\hline
\end{tabular}

Table 4 shows that the highest arithmetic mean of the responses to the instrument was (3.53) for the item 'It is important to do well in mathematics' which means that students can at least see the importance of math in their academic life. The lowest arithmetic mean of the responses to the instrument was (2.05) for the item 'Mathematics is harder for me than any other subject' which means around $41 \%$ of students feel that math is one of the hardest subjects that they have in school.

\subsection{Correlations among Grit, Attitudes toward Math, and Academic Achievement}

Table 5. Correlations between grit, and attitudes toward math level and exam results

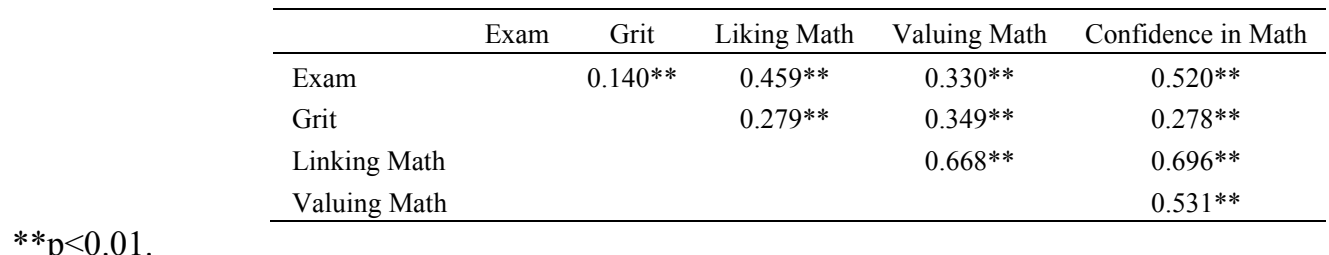

Table 5 shows the correlations between grit scores, and math attitudes; and math academic achievement. From the table we found that grit is positively and significantly correlated to academic achievement in mathematics. Similarly, attitudes to mathematics categories liking mathematics, valuing mathematics, and confidence in mathematics are positively and significantly correlated to math academic achievement. 


\subsection{Descriptive Statistics for Attitudes toward Science Questionnaire}

Table 6. Descriptive statistics of attitudes toward science items categories

\begin{tabular}{lll}
\hline Attitudes toward science items categories & Mean & SD \\
\hline Students like learning science (5 items, from 1-5) & 2.79 & 0.97 \\
Students value science (6 items, from 6-11) & 3.25 & 0.90 \\
Students confident in science (9 items, from 12-20) & 2.70 & 0.93 \\
\hline
\end{tabular}

Table 6 shows that arithmetic mean of the responses to the instrument was (2.79) for Students like learning science items and (2.70) for Students confident in science items. These two categories items showed a moderate level. While Students value science items' arithmetic mean was (3.25) which is a high level. Again as we said in Mathematics and students' items, all these results need to be addressed carefully since they could be important factors affecting achievement negatively.

Table 7. Descriptive statistics of attitudes toward science questionnaire items

\begin{tabular}{|c|c|c|c|}
\hline \multirow{2}{*}{ N. } & \multirow{2}{*}{ Item } & \multicolumn{2}{|c|}{ Science } \\
\hline & & Mean & SD \\
\hline \multicolumn{4}{|c|}{ Liking learning science } \\
\hline 1 & I enjoyed learning science & 3.21 & 0.90 \\
\hline 2 & I wish I did not have to study science & 2.16 & 1.09 \\
\hline 3 & Science is boring & 2.11 & 1.05 \\
\hline 4 & I learn many interesting things in science & 3.36 & 0.82 \\
\hline 5 & I like science & 3.13 & 0.97 \\
\hline \multicolumn{4}{|c|}{ Valuing science } \\
\hline 6 & I think learning science will help me in my daily life & 3.30 & 0.90 \\
\hline 7 & I need science to learn other school subjects & 2.82 & 0.95 \\
\hline 8 & I need to do well in science to get into the university & 3.59 & 0.74 \\
\hline 9 & I need to do well in science to get the job I want & 3.37 & 0.91 \\
\hline 10 & I would like a job at involves using science & 2.86 & 1.12 \\
\hline 11 & It is important to do well in science & 3.53 & 0.75 \\
\hline \multicolumn{4}{|c|}{ Confident in science } \\
\hline 12 & I usually do well in science & 3.23 & 0.77 \\
\hline 13 & Science is more difficult for me than for many of my classmates & 2.00 & 0.97 \\
\hline 14 & Science is not one of my strength & 2.26 & 1.03 \\
\hline 15 & I learn things quickly in science & 3.17 & 0.88 \\
\hline 16 & Science make me confused and nervous & 2.24 & 1.01 \\
\hline 17 & I am good at working out difficult science problems & 2.73 & 0.93 \\
\hline 18 & My teacher thinks I can do well in science & 3.43 & 0.82 \\
\hline 19 & My teacher tells me I am good at science & 3.25 & 0.92 \\
\hline 20 & Science is harder for me than any other subject & 1.98 & 1.06 \\
\hline
\end{tabular}

Table 7 shows that the highest arithmetic mean of the responses to the instrument was (3.59) for the item 'I need to do well in science to get into the university' which means that students can see the importance of doing well in science, as the study results mentioned earlier, students really value the science and believe it is important to them. The lowest arithmetic mean of the responses to the instrument was (1.98) for the item 'Science is harder for me than any other subject' which means around $40 \%$ of the students feel that science is one of the hardest subjects that they have in school. 


\subsection{Correlations among Grit, Attitudes toward Science, and Academic Achievement}

Table 8. Correlations between grit, and attitudes toward science level; and exam results

\begin{tabular}{|c|c|c|c|c|c|}
\hline & Exam & Grit & Liking science & Valuing science & Confidence in science \\
\hline Exam & & 0.071 & $0.282 * *$ & $0.311^{* *}$ & $0.432 * *$ \\
\hline Grit & & & $0.284^{* *}$ & $0.270^{* *}$ & $0.311^{* *}$ \\
\hline Linking science & & & & $0.677 * *$ & $0.633^{* *}$ \\
\hline Valuing science & & & & & $0.509 * *$ \\
\hline
\end{tabular}

$* * \mathrm{p}<0.01$.

Table 8 shows the correlations between grit scores, and science attitudes; and science academic achievement.

From the table we found that there is no significant correlation between grit and academic achievement in science. But we found that attitudes to science categories liking science, valuing science, and confidence in science are positively and significantly correlated to science academic achievement.

\section{Suggestions and Conclusion}

This study was attempted to find if relationships exist between grit, and math and science achievement; between attitude toward mathematics, and math achievement; and finally between attitude toward science and science achievement. As mentioned in the data analysis earlier, attitude showed a positive correlation with math and science achievement. Which mean student attitudes toward mathematics and science is important to be successful in these subjects. Similar results were found in Chiesi and Primi study in 2010; they found that pre-course attitudes were directly linked to anxiety and negative attitudes which yielded to low performance. Results also showed that grit was positively and significantly correlated to academic achievement in mathematics, but did not show a significant correlation with academic achievement in science.

The study results could have a very important influence if considered while teaching mathematics and science to students. Countries of developing economic sectors like gulf region countries especially Bahrain, makes huge effort to develop education. The ministry of education in Bahrain made lots of projects to develop students teaching and learning especially in mathematics, so this study can help in pointing out other important factors like the no-cognitive factors to be considered in future curriculum development. Similar results also were found in (Adebayo, 2008) where he studied the effect of two non-cognitive variables (self-appraisal and understanding racism) on achievement and found that they influenced students' academic success. According to his results, he recommended a new admission selection index to be developed based on these non-cognitive factors.

Mathematics and science are important subjects to achieve the 21 st century skills, which put more pressure on these subject teachers and curriculum developers to find ways to teach in creative ways and use examples that are practical and familiar to students instead of abstract problems which can cause anxiety than failure to understand the subjects and finally low performance. Also, it means that teachers should make the students take an interest in these subjects, to build a good attitude towards them, especially that results showed that some students feel that science and mathematics are boring and difficult subjects. Finally, more research about how the non-cognitive factors can affect math and science performance needed to improve these subjects' outcomes in the country.

\section{References}

Adebayo, B. (2008). Cognitive and non-cognitive factors 'Affecting the Academic Performance and Retention of Conditionally Admitted Freshmen. Journal of college admission, summer, 15-21.

Bengtson, E. D. (2013). How Children Succeed: Grit, Curiosity, and the Hidden Power of Character by Paul Tough, Journal of School Choice: International Research and Reform, 7(1), 100-102. https://doi.org/10.1080/15582159.2013.759845

Burtner, J. (2005). The Use of Discriminant Analysis to Investigate the Influence of Non-Cognitive Factors on Engineering School Persistence. Journal of engineering education, July, 335-338. https://doi.org/10.1002/j.2168-9830.2005.tb00858.x

Chiesi, F., \& Primi, C. (2010). Cognitive and non-cognitive factors related to students' statistics achievement. Statistics Education Research Journal, 9(1), 6-26. Retrieved from http://www.stat.auckland.ac.nz/serj

Culina, V. K., Tsukayama, E., \& Duckworth, A. L. (2014). Unpacking grit: Motivational correlates of 
perseverance and passion for long-term goals. The Journal of Positive Psychology, 9(4), 306-312. https://doi.org/10.1080/17439760.2014.898320

Diaz J. J., Arias O., \& Tudela D. V. (2012). Does Perseverance Pay as Much as Being Smart?: The Returns to Cognitive and Non-cognitive Skills in urban Peru. Retrieved from http://www.iza.org/conference_files/worldb2014/arias_o4854.pdf

Duckwort A., Peterson C., Matthews M. D., \& Kelly D. R. (2007). Grit: Perseverance and Passion for Long-Term Goals. Journal of Personality and Social Psychology, 92(6), 1087-1101. https://doi.org/10.1037/0022-3514.92.6.1087

Duckworth, A., \& Quinn, P. D. (2009). Development and Validation of the Short Grit Scale (Grit-S). Journal of Personality Assessment, 91(2), 166-174. https://doi.org/10.1080/00223890802634290

Gardner, P. L. (1975). Attitudes to Science: A Review. Studies in Science Education, 2(1), 1-41. https://doi.org/10.1080/03057267508559818

Gardner, P. L. (1995). Measuring Attitudes to Science: Unidimensionality and Internal Consistency Revisited. Research in Science Education, 25(3), 283-289. https://doi.org/10.1007/BF02357402

Hanford, E. (2013). Angela Duckworth and the research on 'Grit'. Retrieved from http://americanradioworks.publicradio.org/features/tomorrows-college/

Osborne, J., Simon, S., \& Collins, S. (2003). Attitudes towards science: A review of the literature and its implications. International Journal of Science Education, 25(9), 1049-1079. https://doi.org/10.1080/0950069032000032199

Pajares, F. (2002). Gender and Perceived Self-Efficacy in Self-Regulated Learning, Theory into Practice, 41(2), 116-125. https://doi.org/10.1207/s15430421tip4102_8

Pappano, L. (2013). Grit and the new character education. Harvard Education Letter, 29(1), 1-3.

Reid, N. (2006). Thoughts on attitude measurement. Research in Science \& Technological Education, 24(1), 3-27. https://doi.org/10.1080/02635140500485332

Rojas, J. P. (2015). The relationships among creativity, grit, academic motivation, and academic success in college students (Doctoral Dissertations, University of Kentucky). Retrieved from http://uknowledge.uky.edu/edp_etds/39

Seider, S., \& Soutter, M. (2013). College Access, Student Success, and the New Character Education. Journal of College \& Character, 14(4), 351-356. https://doi.org/10.1515/jcc-2013-0044

Socol, I. (2014). Taking a closer look at the grit narratives. Knowledge Quest/Trends and Foundations: A Closer Look, 43(1), 8-13.

Sommerfeld, A. (2011). Recasting Non-Cognitive Factors in College Readiness as What They Truly Are: Non-Academic Factors. Journal of college admission, 18-22.

Sparks, S. (2015). NAEP to Gather Data on Grit, Mindset. Education Week, June 3, 15. Retrieved from https://www.edweek.org/ga/insideschoolresearch

Stoitz, G. P. (2015). GRIT: The New Science of What it Takes to Persevere, Flourish, Succeed. January 2. Retrieved from http://www.gritinstitute.com/

Tough, P. (2012). How Children Succeed: Grit, Curiosity, and the Hidden Power of Character. New York, NY: Houghton Mifflin Harcourt.

Tsereteli, M., Martskvishvili, K., Aptarashvili, I., Darsavelidze, T., \& Sadzaglishvili, S. (2010). Predicting student's self-competence using school culture factors. Problems of education in the 21st century, 21, 163-169.

Wallace, D. (2010). The Grit in the Oyster-does an appreciation of threshold concepts in an adult literacies teaching qualification result in pearls of practice? Literacy \& Numeracy Studies, 18(1), 3-18. https://doi.org/10.5130/lns.v18i1.1426

Zimmerman, E., \& Brogan, L. (2015). Grit and Legal Education, 36(4), 112-157. Retrieved from http://digitalcommons.pace.edu/plr/vol36/is/s1/4 


\section{Copyrights}

Copyright for this article is retained by the author(s), with first publication rights granted to the journal.

This is an open-access article distributed under the terms and conditions of the Creative Commons Attribution license (http://creativecommons.org/licenses/by/4.0/). 